\title{
TEKNIK DESENSITISASI SISTEMATIS (SYSTEMATIC DESENSITIZATION) DALAM MEREDUKSI GANGGUAN KECEMASAN SOSIAL (SOCIAL ANXIETY DISORDER) YANG DIALAMI KONSELI
}

\author{
Budi Sugiantoro \\ SMK Negeri 1 Kediri \\ toro6194@gmail.com
}

\begin{abstract}
ABSTRAK
Penelitian ini bertujuan untuk mengetahui penerapan teknik desensitisasi sistematis dalam mereduksi gangguan kecemasan sosial yang dialami konseli. Metode penelitian yang digunakan adalah Penelitian Tindakan Kelas/ Layanan (PTK/PTL). Penelitian ini dilakukan dengan 3 siklus dengan hasil siklus pertama tercapai $40 \%$ ketercapaian indikator perubahan yang diinginkan. Pada siklus kedua terakumulasi pencapaian indikator perubahan sebesar $80 \%$ dan pada siklus ketiga semua indikator perubahan tercapai $100 \%$ dari data hasil pengamatan dan wawancara. Berdasarkan pencapaian perubahan indikator pada akhir sikus dapat diambil beberapa kesimpulan antara lain 1) Teknik disensitisasi sistematik efektif untuk mereduksi gangguan kecemasan sosial di sekolah; 2) Efektifitas teknik ini perlu ditunjang dengan penyaluran minat pada ekstrakurikuler, partisipasi guru dan teman serta keinginan kuat konseli untuk mengatasi gangguan yang dialaminya; 3) Konseli memiliki percaya diri rendah sehingga perlu diberikan motivasi; 4) Penyebab gangguan kecemasan yang bersifat menetap yaitu sakit asma dan trauma sulit dihilangkan sehingga gangguan kecemasan sosial ini dikhawatirkan akan muncul pada saat konseli menghadapi situasi yang mengancam.
\end{abstract}

Kata Kunci

desensitisasi sistematis,

kecemasan sosial

Cara mengutip: Sugiantoro, Budi. (2018) Teknik Desensitisasi Sistematis (Systematic Desensitization) dalam Mereduksi Gangguan Kecemasan Sosial (Social Anxiety Disorder) Yang Dialami Konseli. Jurnal Nusantara of Research, 5(1), 72-82.

\section{PENDAHULUAN}

Konseli adalah seorang peserta didik baru tingkat $X$ yang mengalami gangguan kecemasan dan hambatan dalam aktualisasi diri, kesulitan berinteraksi, kesulitan mengikuti diskusi dan praktik di bengkel. Gangguan kecemasan ini disebabkan konseli memiliki sakit asma dan trauma ketika masih di Sekolah Dasar akibat bullying dan pemikiran negatif yang dikembangkan. Memperhatikan latar belakang konseli maka konselor berusaha membantu mengurangi kecemasan dan membimbing pola perilaku konseli menggunakan teknik desensitisasi sistematik (Systematic Desensitization) yaitu mereduksi perilaku cemas yang terkondisikan dengan melakukan aktivitas yang berlawanan dengan respon kecemasan secara bertahap, sedikit demi sedikit dalam suasana rileks sehingga lambat laun konseli dapat merespon faktor-faktor penyebab kecemasannya secara wajar.

Gangguan kecemasan (anxiety disorder ) adalah "Suasana perasaan yang ditandai oleh gejala-gejala jasmaniah seperti ketegangan fisik dan kekhawatiran tentang masa depan (American Psychiatric Association, 1994.,Barlow, 2002)". Sedangkan Sieber (dalam Sudrajat, 
2008) menyatakan bahwa: "kecemasan dianggap sebagai salah satu faktor penghambat dalam belajar yang dapat mengganggu kinerja fungsi-fungsi kognitif seseorang, seperti dalam berkonsentrasi, mengingat, pembentukan konsep dan pemecahan masalah". Sedangkan yang menjadi penyebab dari kecemasan tersebut adalah 1) Faktor Intern, antara lain kemampuan penyesuaian diri, pemikiran-pemikiran negatif (negative thinking); dan 2) Faktor yang berasal dari luar individu yaitu tekanan lingkungan, permasalahan keluarga, pengalaman traumatis, phobia, masalah kehidupan, pendidikan yang salah.

Matson dan Ollendick (dalam Sudarmawan, 2012) mendefinisikan Cognitive Behavioral Therapy sebagai: "Pendekatan dengan sejumlah prosedur yang secara spesifik menggunakan kognisi sebagai bagian utama konseling. Fokus konseling yaitu persepsi, kepercayaan dan pikiran". Dalam konseling CBT ini digunakan suatu teknik yang dinamakan dengan Desensitisasi Sistematik (Systematic Desensitization). Menurut Lutfi Fauzan "Asumsi dasar teknik ini adalah respon ketakutan (sebagai contoh respon ketakutan akan ketinggian) merupakan perilaku yang dipelajari dan dapat dicegah dengan menggantikan aktivitas yang berlawanan dengan respon ketakutan tersebut".

Kecemasan dengan desensitisasi sistematik memiliki korelasi, dimana gangguan kecemasan sosial (social anxiety disorder) adalah gangguan kecemasan neurosis terhadap lingkungan sosial yang ditandai dengan rasa takut atau cemas terhadap penilaian oleh lingkungan sekitarnya. Konseli membangun persepsi negatif terhadap diri sendiri dengan ketidakberdayaan menghadapi kontak sosial. Gangguan kecemasan ini dapat di reduksi dengan proses edukasi untuk mengubah kognitif konseli melalui teknik desensitisasi sistematik dengan melakukan pelemahpekaan (counter conditioning) respon negatif yang dibangun konseli dan menggantikannya dengan aktivitas yang berlawanan untuk mengubah imajinasi konseli menjadi positif. Berdasarkan uraian diatas, terdapat hubungan erat antara gangguan kecemasan social (social anxiety disorder) dengan teknik disentisitisasi sistematik (systematic decentitation) yaitu teknik disensitisasi sistematik merupakan teknik konseling untuk membantu konseli mengubah gangguan kecemasan neurosis yang dialaminya menjadi kecemasan yang wajar.

\section{METODE}

Penelitian ini merupakan penelitian kualitatif dengan desain penelitian tindakan model Penelitian Tindakan Kelas/ Layanan (PTK/PTL). Model rancangan penelitian mengacu model Kemmis dan Mc. Taggart yang menyusun tindakan penelitian dalam siklus - siklus yaitu: 1) perencanaan; 2) aksi/ tindakan; 3) observasi; dan (4) refleksi. Adapun prosedur penelitian yang ditempuh oleh peneliti adalah sebagai berikut: 1) Perencanaan yaitu mengidentifikasi gangguan kecemasan menggunakan angket, pedoman wawancara dan pengamatan; 2) Tindakan yaitu treatment yaitu berupa penerapan teknik desensitisasi sistematis 3) Observasi dilakukan untuk memantau perkembangan konseli setelah melaksanakan diberikan treatment, tahap ini dilakukan dengan cara pengambilan data dengan wawancara dan pengamatan; 4) Refleksi dilakukan dengan menganalisis hasil wawancara, pengerjaan angket dan hasil pengamatan serta dilanjutkan dengan melakukan pengukuran dan penilaian terhadap ketercapaian indikator perubahan kecemasan. 


\section{HASIL \\ Refleksi Awal}

Refleksi awal dari penelitian ini dilakukan untuk menetapkan keadaan awal konseli sebelum diberikan treatment. Dalam merumuskan keadaan awal ini peneliti melakukan refleksi dari hasil wawncara, hasil pengerjaan angket kecemasan dan hasil observasi. Refleksi hasil wawanacara menunjukan bahwa konseli cemas bertemu dengan orang baru, takut berkomunikasi dengan orang baru, merasa cara bicaranya kurang jelas dan takut salah, tertekan dan sulit mengungkapkan perasaan, khawatir salah dalam berdiskusi, membatasi pergaulan, sedih jika mendengar kata-kata kasar, cemas waktu pelajaran di bengkel, kurang percaya diri, trauma dengan sikap guru yang keras.

Sedangkan refleksi hasil pengamatan/ observasi menunjukan bahwa konseli berada pada kondisi yang menunjukan gejala gangguan kecemasan. Hal tersebut ditandai dengan konseli cenderung diam atau tidak aktif, pasif dalma mengikuti pelajaran, sering tidak hadir waktu kegiatan ekstrakurikuler, jarang berkomunikasi/ berkumpul dengan teman, hanya memilih teman tertentu untuk berbaur waktu istirahat, tidak pernah mengobrol dengan guru, suka bersikap gugup ketika bertemu dengan teman baru dan menunjukan prilaku sering diam tanpa respon. Dari pemaparan data yang diperoleh berdasarkan hasil analisis hasil wawncara, angket dan pengamatan dapat diketahui bahwa kecemasan yang dialami oleh konseli lebih mengarah pada Gangguan Kecemasan Sosial (Social Anxiety Disorder).

\section{Hasil Tindakan Siklus 1}

Berdasarkan refleksi awal kemudian melakukan perencanaan. Dalam perencanaan ini peneliti melakukan beberapa kegiatan antara lain 1) menyiapkan skenariao tindakan; 2) menyiapkan instrument observasi/ pengambilan data berupa pedoman wawancara dan pedoman pengamatan; 3) menyiapkan angket refleksi; dan 4) menyiapkan ruangan untuk pengaplikasian tindakan berupa teknik desensitisasi sistematis.

Setelah dilakukan perencaaan maka tahap selanjutnya adalah melakukan aksi/ tindakan dalam upaya mereduksi kecemasan sosial yang dialami oleh konseli. Dalam menerapkan teknik desensitisasi sistematis pada konseli, konselor menempuh beberapa langkah antara lain yaitu: 1) menentukan hirarki kecemasan konseli, kegiatna ini dimaksudkan agar konseli bersama konselor mengetahui hirarki kecemasan konseli sehingga dapat menentukan prioritas mana yang harus di tangani terlebih dahulu; 2) melaksanakan relaksasi, agar konseli merasa tidak tegang atau bahkan cemas; 3) pengkondisian, dimana konseli diajak untuk memasuki kondisi dimana ia mengalami kecemasan; 4) mengajarkan selfregulated learning, dimana konseli diajarkan untuk dapat menguasai kecemasanya sehingga dapat mengontrol dirinya; 5) memberikan tugas rumah, dalam rangka membiasakan diri kepada konseli mengendalikan kecemasanya dan 6) mengisi angket refleksi.

Setelah dilakukan tindakan pada konseli kemudian dilanjutkan dengan observasi atau pengambilan data kembali untuk mengetahui ketercapaian dari penerapan teknik desensitisasi tersebut. Adapun hasil dari pengambilan data tersebut adalah sebagai berikut: 
Table 1. Perbandingan Data Wawancara Awal dengan Wawancara Siklus 1

\begin{tabular}{|c|c|c|c|}
\hline No. & Data Wawancara Awal & Data Wawancara Setelah Perlakuan Siklus 1 & Keterangan \\
\hline 1 & $\begin{array}{l}\text { Konseli merasa cemas ketika } \\
\text { bertemu dengan orang baru. }\end{array}$ & \multirow{2}{*}{$\begin{array}{l}\text { Konseli mencoba untuk mereduksi } \\
\text { kecemasannya secara perlahan-lahan dan } \\
\text { bertahap. }\end{array}$} & $\begin{array}{l}\text { Menunjukan } \\
\text { perkembangan }\end{array}$ \\
\hline 2 & $\begin{array}{l}\text { Konseli merasa takut jika diajak } \\
\text { berkomunikasi dengan orang baru }\end{array}$ & & $\begin{array}{l}\text { Menunjukan } \\
\text { perkembangan }\end{array}$ \\
\hline 3 & $\begin{array}{l}\text { Konseli selalu merasa cara } \\
\text { bicaranya kurang jelas dan takut } \\
\text { salah. }\end{array}$ & & Tetap \\
\hline 4 & $\begin{array}{l}\text { Konseli selalu merasa tertekan dan } \\
\text { sulit mengungkapkan perasaan. }\end{array}$ & $\begin{array}{l}\text { Konseli merasakan perubahan lebih baik } \\
\text { daripada sebelum treatment. }\end{array}$ & $\begin{array}{l}\text { Menunjukan } \\
\text { perkembangan }\end{array}$ \\
\hline 5 & $\begin{array}{l}\text { Konseli selalu merasa khawatir } \\
\text { salah dalam berdiskusi. }\end{array}$ & $\begin{array}{l}\text { Konseli masih mengalami kecemasan dalam } \\
\text { berdiskusi dan lebih bersikap pasif dan merasa } \\
\text { tertekan jika ada teman yang bersikap tidak } \\
\text { sabar. }\end{array}$ & Tetap \\
\hline 6 & $\begin{array}{l}\text { Konseli membatasi pergaulan } \\
\text { dengan teman sebayanya. }\end{array}$ & $\begin{array}{l}\text { Konseli sudah berhasil berkomunikasi dengan } \\
\text { teman sekelas tetapi masih sering ragu dan } \\
\text { masih mengalami kecemasan. }\end{array}$ & $\begin{array}{l}\text { Menunjukan } \\
\text { perkembangan }\end{array}$ \\
\hline 7 & $\begin{array}{l}\text { Konseli merasa sedih jika } \\
\text { mendengar kata-kata kasar. }\end{array}$ & $\begin{array}{l}\text { Konseli bisa menguasai diri, menyadari diri } \\
\text { dan tidak mudah larut dalam emosinya. }\end{array}$ & $\begin{array}{l}\text { Menunjukan } \\
\text { perkembangan }\end{array}$ \\
\hline 8 & $\begin{array}{l}\text { Konseli merasa khawatir dan } \\
\text { cemas waktu pelajaran di bengkel. }\end{array}$ & $\begin{array}{l}\text { Konseli merasa cemas dengan pelajaran } \\
\text { praktik di bengkel karena sebelumnya belum } \\
\text { pernah mengalami praktik. }\end{array}$ & Tetap \\
\hline 9 & Konseli kurang percaya diri. & & Tetap \\
\hline 10 & $\begin{array}{l}\text { Konseli trauma dengan sikap guru } \\
\text { yang keras dan mata pelajaran } \\
\text { tertentu. }\end{array}$ & & Tetap \\
\hline 11 & & $\begin{array}{l}\text { Konseli merasakan lebih bisa menikmati tidur, } \\
\text { sudah tidak susah tidur dan sering bangun } \\
\text { malam. }\end{array}$ & $\begin{array}{l}\text { Menunjukan } \\
\text { perkembangan }\end{array}$ \\
\hline
\end{tabular}

Table 2. Perbandingan Data Pengamatan Awal dengan Pengamatan Siklus 1

\begin{tabular}{|c|c|c|c|c|c|c|}
\hline \multirow{2}{*}{ No. } & \multirow{2}{*}{ Indikator } & \multicolumn{2}{|c|}{ Pengamatan Awal } & \multicolumn{2}{|c|}{ Pengamatan Siklus 1} & \multirow{2}{*}{ Keterangan } \\
\hline & & Perilaku & Nilai & Perilaku & Nilai & \\
\hline 1 & $\begin{array}{l}\text { Pembelajaran di } \\
\text { kelas }\end{array}$ & $\begin{array}{l}\text { Jarang/tidak aktif } \\
\text { mengikuti kegiatan }\end{array}$ & 2 & $\begin{array}{l}\text { Kadang mengikuti } \\
\text { kegiatan }\end{array}$ & 3 & $\begin{array}{l}\text { Ada } \\
\text { perkembangan }\end{array}$ \\
\hline 2 & $\begin{array}{l}\text { Pembelajaran di } \\
\text { bengkel }\end{array}$ & $\begin{array}{l}\text { Serius mengerjakan } \\
\text { tugas }\end{array}$ & 4 & $\begin{array}{l}\text { Serius mengerjakan } \\
\text { tugas }\end{array}$ & 4 & Tetap \\
\hline 3 & $\begin{array}{l}\text { Kegiatan } \\
\text { Ekstrakurikuler }\end{array}$ & Sering tidak hadir & 2 & Kadang tidak hadir & 3 & $\begin{array}{l}\text { Ada } \\
\text { perkembangan }\end{array}$ \\
\hline 4 & $\begin{array}{l}\text { Komunikasi } \\
\text { dengan teman }\end{array}$ & $\begin{array}{l}\text { Jarang ikut } \\
\text { berkumpul }\end{array}$ & 2 & $\begin{array}{l}\text { Berkumpul tapi jarang } \\
\text { mengobrol }\end{array}$ & 3 & $\begin{array}{l}\text { Ada } \\
\text { Perkembangan }\end{array}$ \\
\hline 5 & $\begin{array}{l}\text { Aktivitas dalam } \\
\text { diskusi }\end{array}$ & $\begin{array}{l}\text { Tidak aktif } \\
\text { cenderung diam }\end{array}$ & 1 & $\begin{array}{l}\text { Mengikuti kegiatan tapi } \\
\text { kurang aktif }\end{array}$ & 2 & $\begin{array}{l}\text { Ada } \\
\text { Perkembangan }\end{array}$ \\
\hline 6 & $\begin{array}{l}\text { Penampilan } \\
\text { sehari-hari }\end{array}$ & nampak ceria & 3 & nampak ceria & 3 & Tetap \\
\hline 7 & $\begin{array}{l}\text { Bermain saat } \\
\text { istirahat }\end{array}$ & $\begin{array}{l}\text { Berbaur dengan } \\
\text { teman tertentu }\end{array}$ & 2 & $\begin{array}{l}\text { Bermain dengan } \\
\text { teman tertentu }\end{array}$ & 2 & Tetap \\
\hline 8 & $\begin{array}{l}\text { Komunikasi } \\
\text { dengan guru }\end{array}$ & $\begin{array}{l}\text { Tidak pernah } \\
\text { ngobrol dengan } \\
\text { guru }\end{array}$ & 2 & $\begin{array}{l}\text { Tidak pernah } \\
\text { mengobrol dengan } \\
\text { guru }\end{array}$ & 2 & Tetap \\
\hline 9 & Ekspresi & Diam tanpa respon & 2 & $\begin{array}{l}\text { Merespons pertanyaan } \\
\text { atau candaan teman }\end{array}$ & 3 & $\begin{array}{l}\text { Ada } \\
\text { perkembangan }\end{array}$ \\
\hline 10 & $\begin{array}{l}\text { Sikap terhadap } \\
\text { teman baru }\end{array}$ & Gugup & 2 & $\begin{array}{l}\text { Tenang, tersenyum } \\
\text { dan mengobrol }\end{array}$ & 4 & $\begin{array}{l}\text { Ada } \\
\text { perkembangan }\end{array}$ \\
\hline & & TOTAL SKOR & 22 & & 29 & \\
\hline
\end{tabular}


Berdasarkan data wawancara dapat dipahami bahwa ada indikasi perubahan dimana 5 dari 10 data wawncara awal telah mengalami perkembangan. Disamping itu ada 1 data tambahan yang semula tidak muncul pada wawncara awal, dimana data tersebut mendukung adanya perkembangan konseli kearah perbaikan. Sedangkan dari perbandingan data pengamatan dapat dipahami bahwa dari 10 indikator yang ditetapkan, terdapat 6 indikator yang mengalami perkembangan. Sedangkan secara kuantitatif perkembangan yang konseli dari nilai 22 berkembang menjadi 29. Hal ini mengindikasikan bahwa penerapan teknik desensitisasi sistematis yang terencana dan terlaksana secara sistematis memeberikan dampak yang baik terhadap perkembangan konseli.

\section{Hasil Tindakan Siklus 2}

Perencanaan dalam siklus 2 ini didasarkan pada refleksi pelaksanaan siklus 1 sehingga fokus pada indikator yang belum menunjukan perubahan atau belum menunjukan perubahan yang diharapkan. Dalam tahap persiapan, peneliti melakukan beberapa kegiatan yaitu: mempersiapkan ruangan untuk melakukan treatment, mempersiapkan instrument dan mempersiapkan skenariao tindakan. Setelah kegiatan perencanaan ini dilanjutkan dengan tahap aksi/ tindakan.

Aksi/ tindakan dalam siklus 2 ini dilakukan dengan 1) Tahap Pre-induction, dalam tahap ini konseli diajak untuk membahas topik netral sampai ia benar-benar siap dalam membahas atau belajar mengatasi masalahnya; 2) Tahap Relaksasi, pada tahap ini konseli diajak untuk menjadi rileks membuang kecemasanya. Tahap relaksasi ini merupakan kegiatan yang biasa dilakukan ketika menerapkan teknik desensitisasi sistematis sehingga konseli terbiasa untuk rileks atau anti cemas; 3) Tahap disensitisasi, disini merupakan tahap inti dimana konseli diajak untuk menanggulangi kecemasanya sesuai hirarki yang telah disusun; 4) Home work/ Tugas rumah, tahap ini dilakukan dengan memberikan sjumlah tugas yang harus dikerjakan konseli dirumah dalam rangkan membiasakan konseli untuk dapat mengatasi kecemasanya; dan 5) Self Regulated Learning, diamana konseli diajarkan untuk dapat mengatur segala tindakanya. Setelah dilakukan tindkaan disiklus 2 ini, dilakukan observasi atau pengambilan data kembali melalui wawnacara dan pengamatan.

Table 3. Perbandingan Data Wawancara Siklus 1 dengan Wawancara Siklus 2

\begin{tabular}{clcl}
\hline No. & \multicolumn{1}{c}{$\begin{array}{c}\text { Data Wawancara Setelah } \\
\text { Perlakuan Siklus 1 }\end{array}$} & $\begin{array}{c}\text { Data Wawancara Setelah Perlakuan } \\
\text { Siklus 2 }\end{array}$ & Keterangan \\
\hline 1 & $\begin{array}{l}\text { Konseli mencoba untuk mereduksi } \\
\text { kecemasannya secara perlahan- } \\
\text { lahan dan bertahap. }\end{array}$ & $\begin{array}{l}\text { Perubahan tercapai } \\
\text { di siklus 1 }\end{array}$ \\
\hline $\begin{array}{l}\text { Konseli selalu merasa cara } \\
\text { bicaranya kurang jelas dan takut } \\
\text { salah }\end{array}$ & $\begin{array}{l}\text { Perubahan tercapai } \\
\text { di siklus 1 }\end{array}$ \\
\hline 4 & $\begin{array}{l}\text { Konseli merasakan perubahan lebih } \\
\text { baik daripada sebelum treatment. }\end{array}$ & Tetap \\
\hline $\begin{array}{l}\text { Konseli masih mengalami } \\
\text { kecemasan dalam berdiskusi dan } \\
\text { lebih bersikap pasif dan merasa } \\
\text { tertekan jika ada teman yang } \\
\text { bersikap tidak sabar. }\end{array}$ & $\begin{array}{l}\text { Kerdiskusi. } \\
\text { dalam mengungkapkan pendapat dalam }\end{array}$ \\
\hline
\end{tabular}




\begin{tabular}{|c|c|c|c|}
\hline No. & $\begin{array}{c}\text { Data Wawancara Setelah } \\
\text { Perlakuan Siklus } 1 \\
\end{array}$ & $\begin{array}{c}\text { Data Wawancara Setelah Perlakuan } \\
\text { Siklus } 2 \\
\end{array}$ & Keterangan \\
\hline 6 & $\begin{array}{l}\text { Konseli sudah } \quad \text { berhasil } \\
\text { berkomunikasi dengan teman } \\
\text { sekelas tetapi masih sering ragu dan } \\
\text { masih mengalami kecemasan. }\end{array}$ & & $\begin{array}{l}\text { Perubahan tercapai } \\
\text { di siklus } 1\end{array}$ \\
\hline 7 & $\begin{array}{l}\text { Konseli bisa menguasai diri, } \\
\text { menyadari diri dan tidak mudah larut } \\
\text { dalam emosinya. }\end{array}$ & $\begin{array}{l}\text { Konseli lebih bisa menguasai diri ketika } \\
\text { ada teman yang berkata kasar dan } \\
\text { mencemoh. }\end{array}$ & $\begin{array}{l}\text { Menunjukan } \\
\text { perkembangan }\end{array}$ \\
\hline 8 & $\begin{array}{l}\text { Konseli merasa cemas } \text { dengan } \\
\text { pelajaran praktik di bengkel karena } \\
\text { sebelumnya belum } \quad \text { pernah } \\
\text { mengalami praktik. }\end{array}$ & $\begin{array}{l}\text { - Konseli merasakan perubahan lebih baik } \\
\text { ketika pembelajaran praktik di bengkel, } \\
\text { merasakan lebih bisa menerima kondisi } \\
\text { yang bising di bengkel } \\
\text { - Konseli sudah bisa menyesuaikan diri } \\
\text { dengan aba-aba yang keras dan disiplin } \\
\text { di bengkel }\end{array}$ & $\begin{array}{l}\text { Menunjukan } \\
\text { perkembangan }\end{array}$ \\
\hline 9 & Konseli kurang percaya diri. & $\begin{array}{l}\text { Konseli masih mengalami keragu-raguan } \\
\text { dalam menyampaikan ide sewaktu } \\
\text { bergabung dengan teman-temannya di } \\
\text { SKI. }\end{array}$ & Tetap \\
\hline 10 & $\begin{array}{l}\text { Konseli trauma dengan sikap guru } \\
\text { yang keras dan mata pelajaran } \\
\text { tertentu. }\end{array}$ & $\begin{array}{l}\text { Konseli bisa berkomunikasi dengan lebih } \\
\text { baik dan tidak gagap lagi ketika } \\
\text { menjawab pertanyaan guru }\end{array}$ & $\begin{array}{l}\text { Menunjukan } \\
\text { perkembangan }\end{array}$ \\
\hline 11 & $\begin{array}{l}\text { Konseli merasakan lebih bisa } \\
\text { menikmati tidur, sudah tidak susah } \\
\text { tidur dan sering bangun malam. }\end{array}$ & & $\begin{array}{l}\text { Perubahan tercapai } \\
\text { di siklus } 1\end{array}$ \\
\hline 12 & & $\begin{array}{l}\text { Konseli telah lebih memahami dan } \\
\text { melatih teknik disensitisasi sistematik } \\
\text { sesuai saran konselor }\end{array}$ & $\begin{array}{l}\text { Menunjukan } \\
\text { perkembangan }\end{array}$ \\
\hline 13 & & $\begin{array}{l}\text { Konseli sudah aktif dalam kegiatan Studi } \\
\text { Kerohanian Islam (SKI) di takmir masjid } \\
\text { SMKN } 1 \text { Kediri. }\end{array}$ & $\begin{array}{l}\text { Menunjukan } \\
\text { perkembangan }\end{array}$ \\
\hline
\end{tabular}

Berdasarkan paparan data pada table 3 , treatment pada siklus 2 berhasil meningkatkan kemampuan konseli dalam mengurangi kecemasan pada waktu mengikuti praktik di bengkel. Konseli juga semakin percaya diri dalam menjalin komunikasi dengan guruguru di bengkel maupun guru baru dikelasnya. Meskipun demikian treatment pada siklus 2 ini belum mampu meningkatkan kemampuan konseli untuk mengatasi kecemasannya ketika berdiskusi di kelas. Selanjutnya konseli juga masih merasa cara bicaranya kurang jelas dan takut salah. Serta konseli masih merasa kurang percaya diri, hal ini dapat diketahui dari keragu-raguan dalam menyampaikan ide sewaktu bergabung dengan teman-temannya di SKI.

Table 4. Perbandingan Data Pengamatan Siklus 1 dengan Pengamatan Siklus 2

\begin{tabular}{|c|c|c|c|c|c|c|}
\hline \multirow{2}{*}{ No. } & \multirow{2}{*}{ Indikator } & \multicolumn{2}{|c|}{ Pengamatan Siklus 1} & \multicolumn{2}{|c|}{ Pengamatan Siklus 2} & \multirow{2}{*}{ Keterangan } \\
\hline & & Perilaku & Nilai & Perilaku & Nilai & \\
\hline 1 & $\begin{array}{l}\text { Pembelajaran di } \\
\text { kelas }\end{array}$ & $\begin{array}{l}\text { Kadang mengikuti } \\
\text { kegiatan }\end{array}$ & 3 & & 3 & $\begin{array}{l}\text { Tercapai di } \\
\text { siklus } 1\end{array}$ \\
\hline 2 & $\begin{array}{l}\text { Pembelajaran di } \\
\text { bengkel }\end{array}$ & $\begin{array}{l}\text { Serius } \\
\text { mengerjakan tugas }\end{array}$ & 4 & $\begin{array}{l}\text { Mengerjakan tugas } \\
\text { dengan serius }\end{array}$ & 4 & Tetap \\
\hline 3 & $\begin{array}{l}\text { Kegiatan } \\
\text { Ekstrakurikuler }\end{array}$ & Kadang tidak hadir & 3 & & 3 & $\begin{array}{l}\text { Tercapai di } \\
\text { siklus } 1\end{array}$ \\
\hline 4 & $\begin{array}{l}\text { Komunikasi dengan } \\
\text { teman }\end{array}$ & $\begin{array}{l}\text { Berkumpul tapi } \\
\text { jarang mengobrol }\end{array}$ & 3 & & 3 & $\begin{array}{l}\text { Tercapai di } \\
\text { siklus } 1\end{array}$ \\
\hline 5 & Aktivitas dalam & Mengikuti kegiatan & 2 & Mengikuti kegiatan & 3 & Ada \\
\hline
\end{tabular}




\begin{tabular}{|c|c|c|c|c|c|c|}
\hline \multirow{2}{*}{ No. } & \multirow{2}{*}{ Indikator } & \multicolumn{2}{|c|}{ Pengamatan Siklus 1} & \multicolumn{2}{|c|}{ Pengamatan Siklus 2} & \multirow{2}{*}{ Keterangan } \\
\hline & & Perilaku & Nilai & Perilaku & Nilai & \\
\hline & diskusi & tapi kurang aktif & & $\begin{array}{l}\text { dan cukup aktif } \\
\text { dalam diskusi }\end{array}$ & & Perkembangan \\
\hline 6 & $\begin{array}{l}\text { Penampilan sehari- } \\
\text { hari }\end{array}$ & nampak ceria & 3 & nampak ceria & 3 & Tetap \\
\hline 7 & $\begin{array}{l}\text { Bermain saat } \\
\text { istirahat }\end{array}$ & $\begin{array}{l}\text { Bermain dengan } \\
\text { teman tertentu }\end{array}$ & 2 & $\begin{array}{l}\text { Berbaur dengan } \\
\text { teman lainnya di } \\
\text { dalam kelas }\end{array}$ & 3 & $\begin{array}{l}\text { Ada } \\
\text { Perkembangan }\end{array}$ \\
\hline 8 & $\begin{array}{l}\text { Komunikasi dengan } \\
\text { guru }\end{array}$ & $\begin{array}{l}\text { Tidak pernah } \\
\text { mengobrol dengan } \\
\text { guru }\end{array}$ & 2 & $\begin{array}{l}\text { Kadang-kadang } \\
\text { menanggapi } \\
\text { obrolan Guru }\end{array}$ & 3 & $\begin{array}{l}\text { Ada } \\
\text { Perkembangan }\end{array}$ \\
\hline 9 & Ekspresi & $\begin{array}{l}\text { Merespons } \\
\text { pertanyaan atau } \\
\text { candaan teman }\end{array}$ & 3 & & 3 & $\begin{array}{l}\text { Tercapai di } \\
\text { siklus } 1\end{array}$ \\
\hline 10 & $\begin{array}{l}\text { Sikap terhadap } \\
\text { teman baru }\end{array}$ & $\begin{array}{l}\text { Tenang, } \\
\text { tersenyum dan } \\
\text { mengobrol }\end{array}$ & 4 & $\begin{array}{l}\text { Tenang, tersenyum } \\
\text { dan mengobrol }\end{array}$ & 4 & $\begin{array}{l}\text { Tercapai di } \\
\text { siklus } 1\end{array}$ \\
\hline & & TOTAL SKOR & 29 & & 32 & \\
\hline
\end{tabular}

Dari tabel 4 dapat diketahui bahwa setelah dilakukan aksi/ tindakan pada siklus 2 ini tercapai perubahan pada 3 indikator perubahan yaitu: 1) pada aktivitas diskusi, yang semula kurang aktif menjadi cukup aktif; 2) pada indikator bermain saat istirahat yang semula hanya bermain dengan teman tertentu menjadi mau berbaur dengan teman lainya di dalam kelas; 3 ) dalam hal komunikasi dengan guru, yang tadinya tidak pernah mengobrol dengan guru kemudian terlihat kadang-kadang mau menanggapi obrolan dari guru.

\section{TINDAKAN SIKLUS 3}

Pada siklus ini peneliti melakukan perencanaan berdasarkan hasil refleksi dari pelaksaan tindakan pada siklus 2. Adapaun kegiatan pada perencaan di siklus 3 ini, peneliti melakukan beberapa rangkaian kegiatan antara lain: 1) mempersiapkan ruangan untuk tindakan; 2) mempersiapkan instrument pengambilan data; 3) mempersiapkan skenario tindakan. Setelah perencanaan tersebut dilanjutkan aksi/ tindakan yang dilakukan dengan rangkaian kegiatan antara lain: 1) Pre-induction, dalam rangka menjalin hubungan baik dengan konseli; 2) tahap relaksasi, dalam tahap ini konseli diajak untuk rileks dan merasakan kondisi yang nyaman tanpa adanya kecemasan; 3) tahap desensitisasi sitematis dimana konseli diajak untuk mengatasi permasalahan kecamasan yang dialaminya; 4) tahap pemberian tugas rumah untuk melatih konseli mengatasi kecemasanya secara mandiri; 5) pengajaran self-regulated learning dalam rangka melatih konseli untuk dapat mengendalikan tindakanya; 6) tahap in vivo, tahap ini dilakukasn sebagai upaya membantu konseli mengatasi kecemasan dalam diskusi dengan menciptakan kondisi senyatanya dari situasi yang mencemaskan konseli dengan membentuk kelompok diskusi yang telah dikondisikan.

Setelah dilakukan tindakan pada konseli kemudian dilanjutkan dengan observasi atau pengambilan data kembali untuk mengetahui ketercapaian dari penerapan teknik desensitisasi tersebut. Adapun hasil dari pengambilan data tersebut diperoleh dari hasil wawncara dan pengamatan sebagaimana diuraikan dalam tabel 5 dan tabel 6 berikut: 
Table 5. Perbandingan Data Wawancara Siklus 2 dengan Wawancara Siklus 3

\begin{tabular}{|c|c|c|c|}
\hline No. & $\begin{array}{l}\text { Data Wawancara Setelah } \\
\text { Perlakuan Siklus } 2\end{array}$ & $\begin{array}{c}\text { Data Wawancara Setelah Perlakuan } \\
\text { Siklus } 3\end{array}$ & Keterangan \\
\hline 1 & & & $\begin{array}{l}\text { Perubahan tercapai } \\
\text { di siklus } 1\end{array}$ \\
\hline 2 & & & $\begin{array}{l}\text { Perubahan tercapai } \\
\text { di siklus } 1\end{array}$ \\
\hline 3 & $\begin{array}{l}\text { Konseli selalu merasa cara } \\
\text { bicaranya kurang jelas dan takut } \\
\text { salah }\end{array}$ & $\begin{array}{l}\text { Konseli sudah berani untuk } \\
\text { mengemukakan pendapat sendiri dan } \\
\text { tidak menunjukkan kegugupan ketika } \\
\text { menyampaikan pendapat. }\end{array}$ & $\begin{array}{l}\text { Menunjukan } \\
\text { perkembangan }\end{array}$ \\
\hline 4 & & & $\begin{array}{l}\text { Perubahan tercapai } \\
\text { di siklus } 1\end{array}$ \\
\hline 5 & $\begin{array}{l}\text { Konseli masih mengalami keragu- } \\
\text { raguan dalam mengungkapkan } \\
\text { pendapat dalam berdiskusi. }\end{array}$ & $\begin{array}{l}\text { Konseli telah dapat mengikuti kegiatan } \\
\text { diskusi di kelas lebih baik dari } \\
\text { sebelumnya. }\end{array}$ & $\begin{array}{l}\text { Menunjukan } \\
\text { perkembangan }\end{array}$ \\
\hline 6 & & & $\begin{array}{l}\text { Perubahan tercapai } \\
\text { di siklus } 1\end{array}$ \\
\hline 7 & $\begin{array}{l}\text { Konseli lebih bisa menguasai diri } \\
\text { ketika ada teman yang berkata kasar } \\
\text { dan mencemoh. }\end{array}$ & $\begin{array}{l}\text { Konseli lebih bisa menguasai diri ketika } \\
\text { ada teman yang berkata kasar }\end{array}$ & $\begin{array}{l}\text { Perubahan tercapai } \\
\text { di siklus } 2 \text { dan } \\
\text { disiklus } 3 \text { ada } \\
\text { peningkatan }\end{array}$ \\
\hline 8 & $\begin{array}{l}\text { - Konseli merasakan perubahan lebih } \\
\text { baik ketika pembelajaran praktik di } \\
\text { bengkel, merasakan lebih bisa } \\
\text { menerima kondisi yang bising di } \\
\text { bengkel } \\
\text { - Konseli sudah bisa menyesuaikan } \\
\text { diri dengan aba-aba yang keras dan } \\
\text { disiplin di bengkel }\end{array}$ & & $\begin{array}{l}\text { Perubahan tercapai } \\
\text { di siklus } 2\end{array}$ \\
\hline 9 & $\begin{array}{l}\text { Konseli masih mengalami keragu- } \\
\text { raguan dalam menyampaikan ide } \\
\text { sewaktu bergabung dengan teman- } \\
\text { temannya di SKI. }\end{array}$ & $\begin{array}{l}\text { Konseli sudah bisa mengekpresikan } \\
\text { sikap, sudah bisa tertawa dan bersikap } \\
\text { lebih wajar dengan teman-teman } \\
\text { diskusinya. }\end{array}$ & $\begin{array}{l}\text { Menunjukan } \\
\text { perkembangan }\end{array}$ \\
\hline 10 & $\begin{array}{l}\text { Konseli bisa berkomunikasi dengan } \\
\text { lebih baik dan tidak gagap lagi ketika } \\
\text { menjawab pertanyaan guru }\end{array}$ & & $\begin{array}{l}\text { Perubahan tercapai } \\
\text { di siklus } 2\end{array}$ \\
\hline 11 & & & $\begin{array}{l}\text { Perubahan tercapai } \\
\text { di siklus } 1\end{array}$ \\
\hline 12 & $\begin{array}{l}\text { Konseli telah lebih memahami dan } \\
\text { melatih teknik disensitisasi sistematik } \\
\text { sesuai saran konselor }\end{array}$ & & $\begin{array}{l}\text { Perubahan tercapai } \\
\text { di siklus } 2\end{array}$ \\
\hline 13 & $\begin{array}{l}\text { Konseli sudah aktif dalam kegiatan } \\
\text { Studi Kerohanian Islam (SKI) di } \\
\text { takmir masjid SMKN } 1 \text { Kediri. }\end{array}$ & & $\begin{array}{l}\text { Perubahan tercapai } \\
\text { di siklus } 2\end{array}$ \\
\hline
\end{tabular}

Berdasarkan data hasil wawancara pada tabel 5, dapat diketahui bahwa semua indikator ketercapaian telah tercapai atau dengan kata lain seluruh indikator telah mengalami perkembangan. Dengan ketercapaian perkembangan pada semua indikator maka didasarkan data wawancara ini, siklus penelitian sudah dapat dihentikan, akan tetapi hal tersebut juga harus mempertimbangkan dari hasil pengambilan data melalui teknik pengamatan. Meskipun demikian, jika tindakan harus dilanjutkan ke siklus selanjutnya maka maka kegiatan wawancara tidak dilakukan lagi mengingat semua indikator telah tercapai. 
Table 6. Perbandingan Data Pengamatan Siklus 2 dengan Pengamatan Siklus 3

\begin{tabular}{|c|c|c|c|c|c|c|}
\hline \multirow{2}{*}{ No. } & \multirow{2}{*}{ Indikator } & \multicolumn{2}{|c|}{ Pengamatan Siklus 2} & \multicolumn{2}{|c|}{ Pengamatan Siklus 3} & \multirow{2}{*}{ Keterangan } \\
\hline & & Perilaku & Nilai & Perilaku & Nilai & \\
\hline 1 & $\begin{array}{l}\text { Pembelajaran di } \\
\text { kelas }\end{array}$ & & 3 & & 3 & Tercapai di siklus 1 \\
\hline 2 & $\begin{array}{l}\text { Pembelajaran di } \\
\text { bengkel }\end{array}$ & $\begin{array}{l}\text { Mengerjakan } \\
\text { tugas dengan } \\
\text { serius }\end{array}$ & 4 & $\begin{array}{l}\text { Mengerjakan } \\
\text { tugas dengan } \\
\text { serius }\end{array}$ & 4 & $\begin{array}{l}\text { Tetap, tetapi telah } \\
\text { menunjukan skor } \\
\text { maksimum }\end{array}$ \\
\hline 3 & $\begin{array}{l}\text { Kegiatan } \\
\text { Ekstrakurikuler }\end{array}$ & & 3 & & 3 & Tercapai di siklus 1 \\
\hline 4 & $\begin{array}{l}\text { Komunikasi } \\
\text { dengan teman }\end{array}$ & & 3 & & 3 & Tercapai di siklus 1 \\
\hline 5 & $\begin{array}{l}\text { Aktivitas dalam } \\
\text { diskusi }\end{array}$ & $\begin{array}{l}\text { Mengikuti } \\
\text { kegiatan dan } \\
\text { cukup aktif dalam } \\
\text { diskusi }\end{array}$ & 3 & & 3 & Tercapai di siklus 2 \\
\hline 6 & $\begin{array}{l}\text { Penampilan } \\
\text { sehari-hari }\end{array}$ & nampak ceria & 3 & $\begin{array}{l}\text { Nampak bugar } \\
\text { berpenampilan } \\
\text { rapi }\end{array}$ & 4 & Ada perkembangan \\
\hline 7 & $\begin{array}{l}\text { Bermain saat } \\
\text { istirahat }\end{array}$ & $\begin{array}{l}\text { Berbaur dengan } \\
\text { teman lainnya di } \\
\text { dalam kelas }\end{array}$ & 3 & & 3 & Tercapai di siklus 2 \\
\hline 8 & $\begin{array}{l}\text { Komunikasi } \\
\text { dengan guru }\end{array}$ & $\begin{array}{l}\text { Kadang-kadang } \\
\text { menanggapi } \\
\text { obrolan Guru }\end{array}$ & 3 & & 3 & Tercapai di siklus 2 \\
\hline 9 & Ekspresi & & 3 & & 3 & Tercapai di siklus 1 \\
\hline 10 & $\begin{array}{l}\text { Sikap terhadap } \\
\text { teman baru }\end{array}$ & $\begin{array}{l}\text { Tenang, } \\
\text { tersenyum dan } \\
\text { mengobrol }\end{array}$ & 4 & & 4 & Tercapai di siklus 1 \\
\hline & & TOTAL SKOR & 32 & & 32 & \\
\hline
\end{tabular}

Berdasarkan data pada tabel 6 menunjukan bahwa dari data hasil pengamatan didapatkan bahwa semua indikator ketercapaian telah tercapai seluruhnya. Dengan tercapainya perubahan seluruh indikator dari hasil pengamatan dan digabungkan dengan ketercapaian seluruh indikator dari hasil wawancara maka aksi/ tindakan dengan menggunakan teknik desensitisasi sistematis sudah dapat dihentikan. Dan berdasarkan perkembangan-perkembangan pada masing-masing siklus, menunjukan bahwa penerapan teknik desensitisasi sistematis berhasil dalam mereduksi kecemasan sosial yang dialami oleh konseli.

\section{PEMBAHASAN}

Gangguan kecemasan yang dialami konseli adalah karena faktor trauma dan kurangnya percaya diri akibat sakit asma. Perlakuan yang salah dan kekerasan ketika masih di SD membuat konseli mengembangkan pola berfikir yang salah, cenderung defensive dan menghindar. Pola berfikir ini mempengaruhi pola perilaku dan ekspresi konseli sehari-hari yang mengakibatkan hambatan belajar. Terdapat 10 indikator situasi yang mengakibatkan gangguan kecemasan konseli. Berpijak pada hasil penelitian yang dilakukan oleh Ayu Kim Kurniawan dan Ni Luh Putu Santriani, peneliti menyimpulkan bahwa gangguan kecemasan yang dialami konseli dapat direduksi dengan teknik desensitisasi sistematik. 
Prinsip utama teknik desensitisasi sistematik yaitu relaksasi dan mengubah respon negative menjadi respon positive secara bertahap telah berhasil mengubah gangguan kecemasan konseli menjadi kecemasan wajar. Setelah treatment siklus 1 terdapat perubahan pada 6 indikator, siklus 2 terdapat perubahan 2 indikator dan pada siklus 3 terdapat perubahan 2 indikator, sehingga setelah treatment siklus 1,2, dan 3 seluruh indikator mengalami peningkatan.

Dalam penelitian ini perlu diperhatikan beberapa faktor yang berkembang sesuai dengan kondisi konseli dan kondisi lingkungan yakni penelitian ini cenderung membutuhkan waktu lama karena sensitivitas konseli dengan tingkat emosional yang cukup tinggi sehingga peneliti perlu mencari waktu yang tepat untuk mengajak konseli melakukan teknik desensitisasi sistematik, hal ini terutama sekali terjadi pada tahap awal penelitian. Faktor lain yang berkembang adalah pentingnya memperhatikan bakat, minat dan kebutuhan konseli untuk menciptakan kondisi lingkungan sosial yang mendukung efektifitas teknik desensitisasi sistematis. Peneliti melihat konseli tertarik dengan kegiatan Studi Kerohanian Islam yang merupakan kegiatan ekstrakurikuler yang membuat konseli nyaman sehingga dapat mendukung pelaksanaan teknik desensitisasi sistematik. Disamping kedua faktor tersebut diatas terdapat juga faktor yang penting yaitu dukungan teman-teman konseli dan wali kelas yang membuat kesepakatan untuk tidak membully konseli serta kondisi diskusi-diskusi yang memberi kesempatan konseli untuk mengekspresikan diri.

\section{KESIMPULAN DAN SARAN}

Simpulan yang dapat diambil dari penelitian ini adalah :1) Teknik desensitisasi sistematik efektif untuk mereduksi gangguan kecemasan sosial di sekolah; 2) Efektifitas teknik ini perlu ditunjang dengan penyaluran minat pada ekstrakurikuler, partisipasi guru dan teman serta keinginan kuat konseli untuk mengatasi gangguan yang dialaminya; 3) Konseli mengalami memiliki percaya diri rendah sehingga perlu diberikan motivasi; 4) Penyebab gangguan kecemasan yang bersifat menetap yaitu sakit asma dan trauma sulit dihilangkan sehingga gangguan kecemasan sosial ini dikhawatirkan akan muncul pada saat konseli menghadapi situasi yang mengancam.

Sedangkan saran yang dapat diberikan yaitu untuk Guru Bimbingan dan Konseling agar dapat menggunakan teknik desensitisasi sistematik untuk membantu konseli yang mengalami gangguan kecemasan. Sedangkan untuk Guru mata pelajaran agar lebih memahami karakteristik peserta didik.

\section{DAFTAR RUJUKAN}

Adib, Asrori. 2015. Terapi Kognitif Perilaku Untuk Mengatasi Gangguan Kecemasan Sosial. Jurnal Psychologi, 3(1).

Edy, Purwanto. 2016. Modul Guru Pembelajar Bimbingan dan Konseling untuk SMA-SMK. Jakarta: Dirjen GTK Kemendikbud Republik Indonesia.

Lawrence, A. \& Pervin, dkk. 2010. Psikologi Kepribadian Teori dan Penelitian (alih bahasa). Jakarta: Kencana. 
Gavin Andrew, et all. 2003. The Treatment of Anxiety Disorder. The Edinburgh Building, Cambridge, United Kingdom: Cambridge University Press.

Hamid, Patilima. 2007. Metode Penelitian Kualitatif. Bandung: Alfabeta.

J.Wright, Robert. 2014. Research methods for Counseling: an introduction. United States of America: Widener University,SAGE Publications.

Fauzan, Lutfi. 2007. Systematic Desensitization: Prosedur pelemah pekaan berangsur terhadap Gangguan Phobia dan Kecemasan. Malang: Departemen Pendidikan Nasional Universitas Negeri Malang UPT Bimbingan dan Konseling.

Aryani, N. L. P.S., Suarni, Ni Ketut \& Putri, D. A. W. M. 2014. Penerapan Konseling Behavioral dengan Teknik Desensitisasi Sistematis untuk Meminimalisir Kecemasan Siswa dalam Menyampaikan Pendapat Kelas VIII 10 SMP Negeri 2 SingarajanTahun Pelajaran 2013/ 2014. Jurusan Bimbingan dan Konseling Undhiska, 2(1).

S. Hall., Calvin dan Gardner, Lindzey, Supratiknya A. (Ed.). 1995. Psikologi Kepribadian 1: Teori-teoriPsikodinamik (Klinis). Yogyakarta: Kanisius.

Savitri, Rahmaiah. 2003. Kecemasan Bagaimana Mengetahui Penyebabnya. Jakarta: Pustaka Populer Obor.

Wela, Aswida, Marjohan, \& Yarmis, Syukur. 2012. Efektifitas layanan Bimbingan Kelompok dalam Mengurangi Kecemasan Berkomunikasi pada Siswa. KONSELOR, 1(2) 1-11. 